\title{
Tiga Pilar Usaha Ternak : Breeding, Feeding, and Management
}

\author{
Three Pillars of Livestock Farming Business : Breeding, Feeding, and Management
}

\author{
Amam $^{1,2}$ dan P. A. Harsita ${ }^{1}$ \\ ${ }^{1}$ PS Peternakan, Fakultas Pertanian, Universitas Jember, Indonesia \\ ${ }^{2}$ PS Agribisnis, Fakultas Pertanian, Universitas Jember, Indonesia \\ Corresponding Author: amam.faperta@unej.ac.id
}

\begin{abstract}
Livestock business can not be separated from the "golden triangle" concept, namely breeding, feeding, and management. This research aimed to evaluate of classical asumption for the "golden triangle" concept of livestock business with approach on the expost factor research, so that this research can update for literature review. The research was carried out in the dairy cattle business in the Kawasan Peternakan Sapi Perah Nasional (KPSPN) of Malang District, East Java. Respondents are all dairy farmers who are members of farmer institutional of the KUB (Kelompok Usaha Bersama) Tirtasari Kresna Gemilang which consists of 174 people. Data was analyzed by PLS (Partial Least Square) method with Smart PLS. The results showed that dairy cattle farming was determined by breeding, feeding and management as the main pillars of $86 \%$, while the remaining $14 \%$ is influenced by other factors not included in the model. The conclusions from the research are three pillars of dairy cattle business, namely breeding, feeding, and management.
\end{abstract}

Key words: breeding, feeding, management, livestock business, dan dairy cattle.

\begin{abstract}
ABSTRAK
Usaha ternak tidak bisa terlepas dari konsep "segi tiga emas" yaitu breeding, feeding, and management. Penelitian ini bertujuan untuk menguji asumsi klasik terhadap konsep "segi tiga emas" usaha ternak melalui pendekatan expost facto research, sehingga dapat memperbarui tinjauan literatur. Penelitian dilakukan pada usaha ternak sapi perah di Kawasan Peternakan Sapi Perah Nasional (KPSPN) Kabupaten Malang, JawaTimur. Responden adalah semua peternak sapi perah yang tergabung di dalam kelembagaan peternak KUB (Kelompok Usaha Bersama) Tirtasari Kresna Gemilang yang beranggotakan 174 orang. Data dianalisis menggunakan metode PLS (Partial Least Square) dengan Smart PLS. Hasil penelitian menunjukkan bahwa usaha ternak sapi perah dipengaruhi oleh breeding, feeding, and management sebagai pilar utama sebesar $86 \%$, sedangkan sisanya sebesar $14 \%$ dipengaruhi oleh faktor lain yang tidak terdapat di dalam model. Kesimpulan dari penelitian yaitu terdapat tiga pilar utama usaha ternak sapi perah, yaitu breeding, feeding, and management.
\end{abstract}

Kata kunci: breeding, feeding, management, usaha ternak, dan sapi perah.

\section{PENDAHULUAN}

Usaha ternak tidak bisa terlepas dari konsep "segitiga emas", yaitu breeding, feeding, and management, termasuk usaha ternak sapi perah di era modern. Pembibitan sapi perah menjadi pilar penting dalam usaha ternak mengingat pembibitan adalah suatu kegiatan pemeliharaan ternak dengan tujuan utama pembibitan ternak. Peraturan Menteri Pertanian Nomor 100/ Permentan /OT.140/ 7/2014 tentang Pedoman Pembibitan Sapi Perah yang Baik menyebutkan bahwa bibit merupakan salah satu faktor yang menentukan dalam upaya pengembangan sapi perah. Pembibitan adalah kegiatan budidaya yang menghasilkan bibit ternak untuk keperluan sendiri atau diperjualbelikan.

Firman et al. (2010) menyatakan bahwa usaha perbibitan pada peternakan sapi perah memegang peranan penting dalam penyediaan stock bibit sapi perah. Perbibitan atau breeding merupakan bagian yang tidak terpisahkan dari siklus breeding, feeding, and management. Ketiga faktor tersebut sangat penting dalam usaha ternak sapi perah. Peningkatan produktivitas ternak dapat dicapai melalui perbaikan genetik, pakan, 
manajemen, dan modifikasi lingkungan (Anggraeni dan Mariana, 2016).

Pakan sebagai salah satu pilar utama usaha ternak mempunyai peranan penting mengingat tinggi dan rendahnya biaya produksi sangat dipengaruhi oleh besar dan kecilnya biaya pakan. Agustono et al. (2017) menyebutkan bahwa pakan merupakan salah satu aspek terpenting dalam pengelolaan peternakan. Ketersediaan pakan di musim hujan dan musim kemarau harus tetap ada. Mariyono dan Krishna (2009) menambahkan bahwa pakan yang bersumber dari hasil ikutan pertanian bersifat terbatas dengan harga yang fluktuatif.

Undang-undang Republik Indonesia Nomor 18 Tahun 2009 tentang Peternakan dan Kesehatan Hewan menyebutkan bahwa pakan adalah bahan makanan tunggal atau campuran, baik yang diolah maupun yang tidak diolah, yang diberikan pada hewan (ternak) untuk kelangsungan hidup, berproduksi, serta berkembangbiak. Syam et al. (2016) menyatakan bahwa pakan ternak ruminansia terdiri dari pakan hijauan dan pakan konsentrat (penguat). Upaya peningkatan produksi susu sapi perah yang sedang laktasi ialah melalui pemberian rumput yang dikombinasikan dengan jerami jagung fermentasi serta penambahan pakan konsentrat (Nurhayu et al., 2017).

Manajemen merupakan salah satu pilar utama usaha ternak. Manajemen usaha ternak yang buruk dan masih bersifat tradisional merupakan salah satu penyebab rendahnya produktivitas sapi perah (Sulistyati et al., 2013). Konsep GDFP (Good Dairy Farming Practices) menyebutkan bahwa manajemen usaha ternak sapi perah yang baik meliputi: kesehatan ternak, higienitas susu, nutrisi ternak (pakan dan minum), kesejahteraan ternak, perkandangan dan lingkungan, dan manajemen sosial ekonomi.
Uraian di atas menggambarkan pentingnya tiga pilar usaha ternak yang terdiri dari breeding, feeding, and management. Penelitian ini bertujuan untuk menguji asumsi klasik terhadap konsep "segitiga emas" usaha ternak sapi perah melalui pendekatan expost facto research, sehingga dapat memperbarui tinjauan literatur di era industri 4.0. Hipotesis menunjukkan bahwa usaha ternak dipengaruhi oleh breeding, feeding, and management.

\section{MATERI DAN METODE}

Penelitian dilakukan pada bulan November 2018 sampai dengan bulan Februari 2019 di Kawasan Peternakan Sapi Perah Nasional (KPSPN) Kabupaten Malang, Provinsi Jawa Timur. Responden merupakan kelembagaan peternak KUB (Kelompok Usaha Bersama) Tirtasari Kresna Gemilang yang terdiri dari 174 peternak sapi perah. Sampel penelitian adalah semua peternak anggota KUB Tirtasari Kresna Gemilang (total sampling).

Penelitian menggunakan pendekatan expost facto research untuk menguji tiga pilar usaha ternak (breeding, feeding, and management). Metode pengumpulan data menggunakan kuisioner (pengisian angket), wawancara, dan observasi secara langsung untuk mendapatkan informasi yang akurat. Data kemudian dianalisis menggunakan metode PLS (Partial Least Square) dengan Smart PLS. Wiyono (2011) menyatakan bahwa salah satu manfaat penggunaan SmartPLS ialah untuk menguji teori yang lemah atau menemukan teori yang baru.

Penelitian ini terdiri dari 4 variabel utama, yaitu: breeding, feeding, and management, serta usaha ternak sapi perah.Variabel dan indikator penelitian dapat dilihat pada Tabel 1 di bawah ini 
Tabel 1. Variabel dan Indikator Penelitian

\begin{tabular}{|c|c|c|}
\hline Variabel & Indikator & Notasi \\
\hline Breeding $\left(\mathrm{X}_{1}\right)$ & $\begin{array}{l}\text { kriteria calon induk jantan } \\
\text { kriteria calon induk betina } \\
\text { umur induk } \\
\text { kawin alami } \\
\text { kawin suntik } \\
\text { calving interval } \\
\text { service per conception } \\
\text { tata kelola reproduksi }\end{array}$ & $\begin{array}{l}\mathrm{X}_{1.1} \\
\mathrm{X}_{1.2} \\
\mathrm{X}_{1.3} \\
\mathrm{X}_{1.4} \\
\mathrm{X}_{1.5} \\
\mathrm{X}_{1.6} \\
\mathrm{X}_{1.7} \\
\mathrm{X}_{1.8}\end{array}$ \\
\hline Feeding $\left(\mathrm{X}_{2}\right)$ & $\begin{array}{l}\text { pakan hijauan dari jenis rerumputan } \\
\text { pakan hijauan dari jenis dedaunan } \\
\text { pakan dari bijian-bijian } \\
\text { pakan dari limbah pertanian } \\
\text { pakan dari limbah industri } \\
\text { pakan konsentrat (penguat) } \\
\text { minum } \\
\text { nutrisi tambahan }\end{array}$ & $\begin{array}{l}\mathrm{X}_{2.1} \\
\mathrm{X}_{2.2} \\
\mathrm{X}_{2.3} \\
\mathrm{X}_{2.4} \\
\mathrm{X}_{2.5} \\
\mathrm{X}_{2.6} \\
\mathrm{X}_{2.7} \\
\mathrm{X}_{2.8}\end{array}$ \\
\hline Management $\left(\mathrm{X}_{3}\right)$ & $\begin{array}{l}\text { perkandangan } \\
\text { biosekuriti } \\
\text { pemeliharaan sapi pedet } \\
\text { pemeliharaan sapi lepas sapih } \\
\text { pemeliharaan sapi dara } \\
\text { pemeliharaan sapi bunting } \\
\text { pemeliharaan sapi laktasi } \\
\text { pemeliharaan sapi kering } \\
\text { pemeliharaan induk jantan } \\
\text { pemeliharaan induk betina } \\
\text { recording } \\
\text { tingkah laku ternak } \\
\text { manajemen lingkungan } \\
\text { manajemen bisnis } \\
\text { kelembagaan peternak } \\
\text { manajemen sumber daya } \\
\text { sarana dan prasarana } \\
\text { kesehatan ternak } \\
\text { penanganan limbah } \\
\text { panen } \\
\text { pengolahan hasil } \\
\text { pemasaran dan distribusi }\end{array}$ & $\begin{array}{l}X_{3.1} \\
X_{3.2} \\
X_{3.3} \\
X_{3.4} \\
X_{3.5} \\
X_{3.6} \\
X_{3.7} \\
X_{3.8} \\
X_{3.9} \\
X_{3.10} \\
X_{3.11} \\
X_{3.12} \\
X_{3.13} \\
X_{3.14} \\
X_{3.15} \\
X_{3.16} \\
X_{3.17} \\
X_{3.18} \\
X_{3.19} \\
X_{3.20} \\
X_{3.21} \\
X_{3.22}\end{array}$ \\
\hline Usaha ternak sapi perah $\left(\mathrm{Y}_{1}\right)$ & $\begin{array}{l}\text { skala usaha } \\
\text { populasi ternak yang dipelihara } \\
\text { pengalaman usaha ternak }\end{array}$ & $\begin{array}{l}\mathrm{Y}_{1.1} \\
\mathrm{Y}_{1.2} \\
\mathrm{Y}_{1.3}\end{array}$ \\
\hline
\end{tabular}

433 | Tiga pilar usaha ternak : breeding, feeding, and management (Amam dan Harsita, 2019) 


\section{HASIL DAN PEMBAHASAN}

Sapi perah dibudidayakan dan dikembangkan secara khusus untuk memproduksi susu. Tinggi dan rendahnya produksi susu sangat bergantung pada banyak faktor. Usaha ternak sapi perah terdapat tiga pilar utama yang terdiri dari breeding, feeding, and management. Ketiga pilar tersebut dilakukan pengujian terhadap semua indikator yang mendukung variabelnya. Hasil uji indikator tersebut dapat dilihat pada Tabel 2 di bawah ini:

Tabel 2. Hasil Uji Indikator

\begin{tabular}{lcrlcc}
\hline Indicator & Outer Loading & result & Indicator & Outer Loading & result \\
\hline $\mathrm{X}_{1.2}$ & 0.754 & valid & $\mathrm{X}_{3.5}$ & 0.612 & valid \\
$\mathrm{X}_{1.3}$ & 0.544 & valid & $\mathrm{X}_{3.6}$ & 0.719 & valid \\
$\mathrm{X}_{1.5}$ & 0.826 & valid & $\mathrm{X}_{3.7}$ & 0.868 & valid \\
$\mathrm{X}_{1.6}$ & 0.698 & valid & $\mathrm{X}_{3.8}$ & 0.596 & valid \\
$\mathrm{X}_{1.7}$ & 0.673 & valid & $\mathrm{X}_{3.10}$ & 0.675 & valid \\
$\mathrm{X}_{1.8}$ & 0.567 & valid & $\mathrm{X}_{3.14}$ & 0.855 & valid \\
$\mathrm{X}_{2.1}$ & 0.914 & valid & $\mathrm{X}_{3.15}$ & 0.924 & valid \\
$\mathrm{X}_{2.3}$ & 0.728 & valid & $\mathrm{X}_{3.16}$ & 0.869 & valid \\
$\mathrm{X}_{2.4}$ & 0.846 & valid & $\mathrm{X}_{3.17}$ & 0.515 & valid \\
$\mathrm{X}_{2.6}$ & 0.774 & valid & $\mathrm{X}_{3.18}$ & 0.572 & valid \\
$\mathrm{X}_{2.7}$ & 0.895 & valid & $\mathrm{X}_{3.20}$ & 0.885 & valid \\
$\mathrm{X}_{3.1}$ & 0.766 & valid & $\mathrm{Y}_{1.1}$ & 0.534 & valid \\
$\mathrm{X}_{3.3}$ & 0.623 & valid & $\mathrm{Y}_{1.2}$ & 0.849 & valid \\
$\mathrm{X}_{3.4}$ & 0.560 & valid & $\mathrm{Y}_{1.3}$ & 0.917 & valid \\
\hline
\end{tabular}

Sumber : Data diolah (2019)

Keterangan : Nilai Outer Loading setelah menghilangkan indikator tidak valid

Nilai outer loading yang dinyatakan valid dan memenuhi syarat yaitu $>0.500$, sehingga indikator yang memiliki nilai outer loading kurang dari 0.500 akan dihapus dari model. Indikator variabel breeding yang tidak memenuhi syarat yaitu kriteria calon induk jantan dan kawin alami. Peternak sapi perah yang tergabung di dalam Kelompok Usaha Bersama (KUB) Tirtasari Kresna Gemilang mengandalkan kawin suntik dengan metode Inseminasi Buatan (IB), sehingga ketergantungan terhadap calon induk jantan dan kawin alami menjadi berkurang, hal tersebut berdampak pada lemahnya indikator dari calon induk jantan dan kawin alami terhadap breeding pada usaha ternak sapi perah. Susilawati (2011) menyatakan bahwa IB merupakan salah satu teknologi reproduksi yang bertujuan untuk meningkatkan efisiensi produksi dan penyebaran bibit unggul dan dapat mencegah penularan penyakit dari kelamin.
Indikator variabel feeding yang tidak memenuhi syarat yaitu pakan hijauan dari jenis dedaunan, pakan dari limbah industri, dan nutrisi tambahan. Peternak sapi perah yang tergabung di dalam KUB Tirtasari Kresna Gemilang mendapatkan suplai pakan dari kelompok (kelembagaan), sehingga kecil kemungkinan menggunakan pakan dari limbah industri dan nutrisi tambahan, sedangkan pakan hijauan dari jenis dedaunan terbatas jumlahnya. Handayanta (2002) menjelaskan bahwa ketersediaan sumber pakan dari hijauan sering mengalami kendala akibat dari tidak terjaminnya kontinyuitas produksi hijauan dan zat anti nutrisi yang terkandung di dalam hijauan tersebut.

Indikator variabel management yang tidak memenuhi syarat yaitu biosekuriti, pemeliharaan induk jantan, recording, tingkah laku ternak, manajemen lingkungan, pengolahan limbah, pengolahan hasil, serta pemasaran dan distribusi. Peternak sapi perah yang tergabung di dalam KUB Tirtasari 
Kresna Gemilang tidak menerapkan biosekuriti karena membutuhkan biaya yang besar. Recording, pengolahan limbah, dan pengolahan hasil belum dilakukan peternak karena minimnya SDM dan rendahnya daya dukung dari kelembagaan. Pemeliharaan induk jantan masih jarang dilakukan peternak karena umumnya lebih fokus dengan sapi betina, sehingga pejantan dijual untuk digemukkan. Pemasaran dan distribusi tidak secara langsung dilakukan oleh peternak sapi perah, melainkan oleh kelompok peternak (kelembagaan), sehingga dengan adanya kelembagaan dapat meningkatkan posisi tawar peternak (Nasrul, 2012). Amam dan Soetriono (2019) menyatakan bahwa kelembagaan peternakan berperan bukan hanya untuk tindakan preventif peternak untuk mengurangi risiko bisnis namun juga berperan sebagai pengembangan usaha ternak untuk mensejahterakan anggotanya.

\section{Uji Model}

Metode PLS (Partial Least Square) dalam SEM (Structural Equation Model) dengan SmartPLS menghasilkan kriteria uji struktural berupa nilai AVE (Average Variance Extracted), nilai CR (Composite Reliability), RSquare $\left(\mathrm{R}^{2}\right)$, dan nilai $\mathrm{CA}$ (Cronbach Alpha's). Hasil uji struktural atau uji hipotesis pada model ini dapat dilihat pada Tabel 3.

Uji model dengan PLS terdiri dari nilai koefisien determinasi $\left(\mathrm{R}^{2}\right)$, nilai $\mathrm{t}$ statistik, dan nilai koefisien parameter. Hasil uji model dapat dilihat pada Tabel 4 .

Tabel 3. Uji Struktural

\begin{tabular}{ccccc}
\hline & Average Variance Extracted & Composite Reliability & $R$ Square & Cronbach's Alpha \\
\hline $\mathrm{X}_{1}$ & 0.661 & 0.887 & 0.850 \\
$\mathrm{X}_{2}$ & 0.695 & 0.822 & 0.767 \\
$\mathrm{X}_{3}$ & 0.684 & 0.818 & 0.615 \\
$\mathrm{Y}_{1}$ & 0.679 & 0.824 & 0.861 & 0.612 \\
\hline
\end{tabular}

Sumber: Output SmartPLS

Tabel 4. Uji Model

\begin{tabular}{lc}
\hline \multicolumn{1}{c}{ Pengujian } & Hasil Uji \\
\hline Koefisien Determinasi $\left(\mathrm{R}^{2}\right)$ & 0.861 \\
\hline Usaha ternak sapi perah & 4.126 \\
\hline $\mathrm{t}$-statistik & 4.824 \\
$\mathrm{X}_{1} \rightarrow \mathrm{Y}_{1}$ & 5.747 \\
$\mathrm{X}_{2} \rightarrow \mathrm{Y}_{1}$ & \\
$\mathrm{X}_{3} \rightarrow \mathrm{Y}_{1}$ & 0.289 \\
\hline Koefisien Parameter & 0.352 \\
$\mathrm{X}_{1} \rightarrow \mathrm{Y}_{1}$ & 0.495 \\
$\mathrm{X}_{2} \rightarrow \mathrm{Y}_{1}$ & \\
$\mathrm{X}_{3} \rightarrow \mathrm{Y}_{1}$ &
\end{tabular}

Sumber: Output SmartPLS 


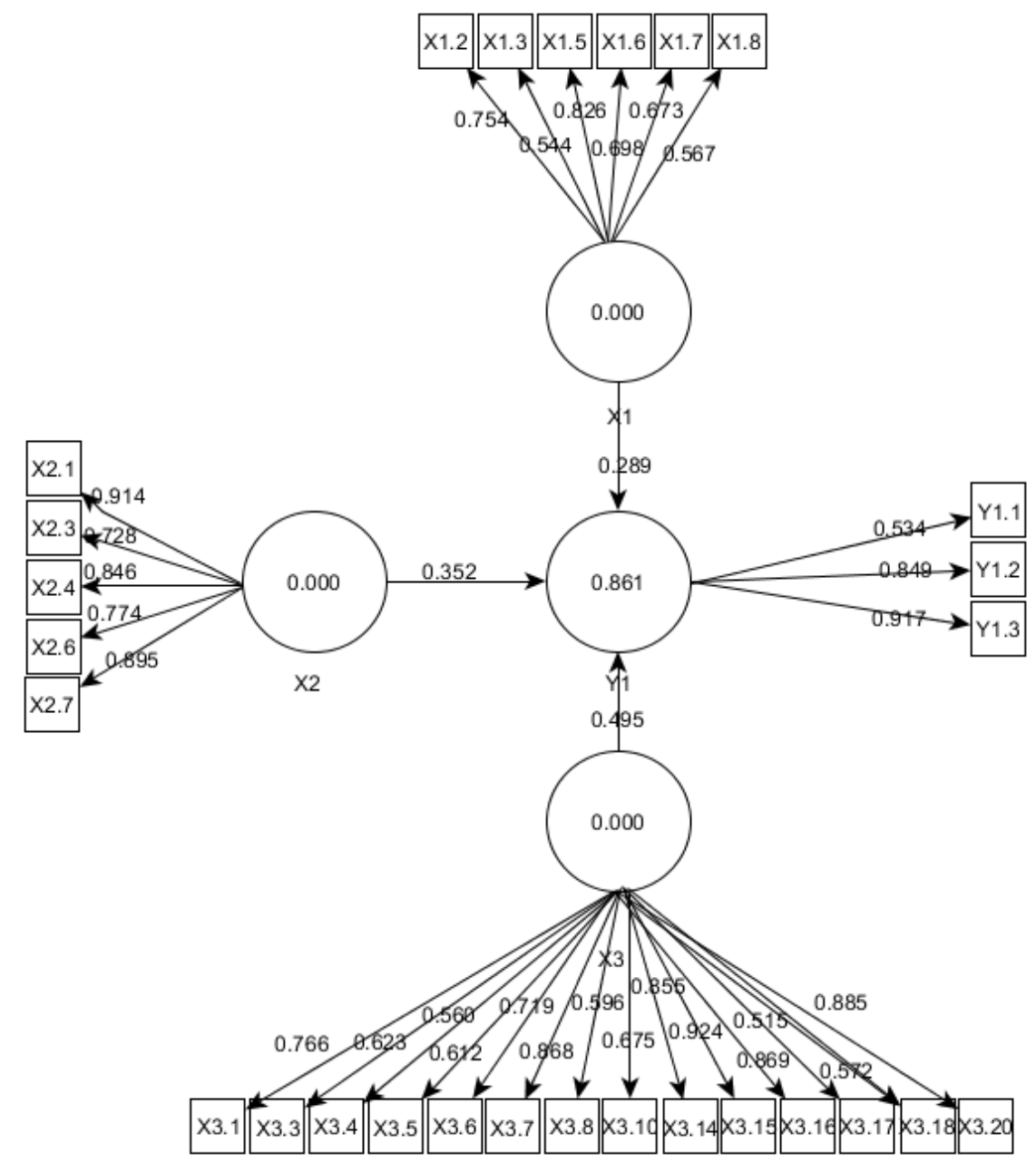

Gambar 1. Hasil Logaritma PLS

\section{Usaha Ternak Sapi Perah}

Tiga pilar utama usaha yang terdiri dari breeding, feeding, and management mempengaruhi usaha ternak sapi perah sebesar 86\%, sedangkan sisanya sebesar $14 \%$ dipengaruhi oleh faktor lain yang tidak terdapat di dalam model. Amam dan Harsita (2019) menyatakan bahwa SDM (Sumber Daya Manusia) peternak sapi perah secara positif dipengaruhi oleh performa kelembagaan dan aspek risiko bisnis, sedangkan SDM peternak sapi perah secara negatif dipengaruhi oleh pengembangan usaha.

Usaha ternak sapi perah tidak bisa terlepas dari breeding, feeding, and management. Ketiga pilar tersebut berpengaruh secara positif terhadap usaha ternak sapi perah. Breeding mempengaruhi usaha ternak sapi perah sebesar 0.289, feeding mempengaruhi usaha ternak sapi perah sebesar 0.352, dan management mempengaruhi usaha ternak sapi perah sebesar 0.495. Peternak sapi perah yang tergabung di dalam Kelompok Usaha Bersama (KUB) Tirtasari Kresna Gemilang secara garis besar sudah menerapkan konsep breeding, feeding, and management dengan baik, sehingga ketiga pilar tersebut berpengaruh secara positif terhadap usaha ternak sapi perah. Peran serta kelembagaan sebagai upaya untuk pengembangan usaha ternak sangat memungkinkan mengingat posisi tawar peternak yang lemah (Nasrul, 2012). Amam dan Soetriono (2019) menyatakan bahwa performa kelembagaan berpengaruh positif terhadap pengembangan usaha ternak sapi perah. 


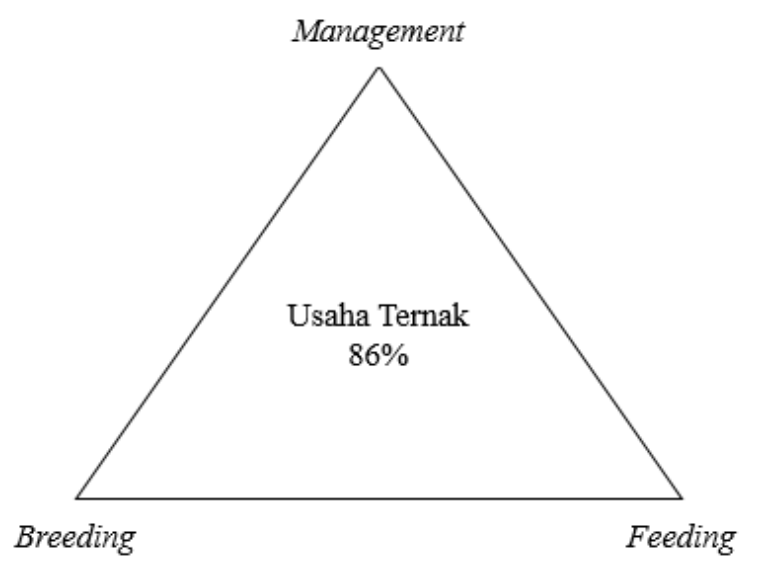

Gambar 2. Konsep "Segitiga Emas" Usaha Ternak Berdasarkan Output PLS

\section{Breeding}

Usaha ternak sapi perah dipengaruhi secara positif oleh breeding sebesar 0,289, artinya bahwa breeding merupakan bagian penting dari usaha ternak sapi perah. Breeding pada sapi perah terdiri dari kriteria calon induk betina, umur induk, kawin suntik, calving interval, service per conception, dan tata kelola reproduksi.

Peternak sapi perah di KUB Tirtasari Kresna Gemilang secara keseluruhan sudah menerapkan breeding yang cukup baik pada usaha ternak sapi perah sesuai dengan Peraturan Menteri Pertanian Nomor 100/Permentan/OT.140/7/2014 tentang Pedoman Pembibitan Sapi Perah yang Baik Makin dan Suharwanto (2012) menyatakan bahwa kemampuan performa produksi susu sapi perah sangat bergantung pada faktor genetik dan faktor lingkungan yang mencakup aspek reproduksi, pakan, serta tatalaksana yang baik.

\section{Feeding}

Usaha ternak sapi perah dipengaruhi secara positif oleh feeding sebesar 0,352, artinya bahwa feeding merupakan bagian penting dari usaha ternak sapi perah. Feeding pada sapi perah terdiri dari pakan hijauan dari jenis rerumputan, pakan dari biji-bijian, pakan dari limbah pertanian, pakan konsentrat, dan minum.

Peternak sapi perah di KUB Tirtasari Kresna Gemilang secara keseluruhan sudah menerapkan feeding yang cukup baik pada usaha ternak sapi perah sesuai dengan Undang-undang Republik Indonesia Nomor 18 Tahun 2009 tentang Peternakan dan Kesehatan Hewan. Sunu et al. (2013) menyebutkan bahwa untuk mengoptimalkan produksi susu, pemberian pakan sapi perah bukan hanya berasal dari hijauan, melainkan dibutuhkan perbaikan kualitas pakan dengan peningkatan protein pakan, sedangkan untuk konsumsi air minum sapi perah diberikan secara ad libitum (Riski et al., 2016).

\section{Management}

Usaha ternak sapi perah dipengaruhi secara positif oleh management sebesar 0,495, artinya bahwa management merupakan bagian penting dari usaha ternak sapi perah. Management pada sapi perah terdiri dari perkandangan, pemeliharaan sapi pedet, pemeliharaan sapi lepas sapih, pemeliharaan sapi dara, pemeliharaan sapi bunting, pemeliharaan sapi laktasi, pemeliharaan sapi kering, pemeliharaan induk betina, manajemen bisnis, kelembagaan peternak, manajemen sumber daya, sarana dan prasarana, kesehatan ternak, dan panen.

Peternak sapi perah di KUB Tirtasari Kresna Gemilang secara keseluruhan sudah menerapkan management yang cukup baik pada usaha ternak sapi perah sesuai dengan Konsep GDFP (Good Dairy Farming Practices). Amam et al. (2019) menyebutkan bahwa pengembangan usaha ternak sapi perah dipengaruhi oleh SDM peternak dan akses peternak terhadap sumber daya. Hal tersebut menunjukkan bahwa SDM dan sumber daya turut berperan terhadap variabel management secara keseluruhan.

\section{KESIMPULAN}

Konsep "segitiga emas" yang terdiri dari breeding, feeding, and management yang merupakan tiga pilar utama pada usaha ternak mempengaruhi usaha ternak sapi perah sebesar 86\%, sedangkan sisanya sebesar $14 \%$ dipengaruhi oleh faktor lain yang tidak terdapat di dalam model. Ketiga 
pilar tersebut secara positif mempengaruhi usaha ternak sapi perah. Breeding memiliki pengaruh sebesar 0,289; feeding memiliki pengaruh sebesar 0,352 ; dan management memiliki pengaruh sebesar 0,495 .

Tiga pilar utama usaha ternak yang terdiri dari breeding, feeding, and management mempunyai peranan penting pada subsektor peternakan, namun pesatnya perkembangan teknologi dan informasi di era industri 4.0, sangat memungkinkan faktorfaktor lain mempunyai dampak yang besar terhadap usaha ternak di era modern mengingat tiga pilar tersebut hanya mempengaruhi usaha ternak sapi perah sebesar $86 \%$.

\section{DAFTAR PUSTAKA}

Agustono, B., M. Lamid, A. Ma'ruf, dan M. T. E. Purnama. 2017. Identifikasi Limbah Pertanian dan Perkebunan sebagai Bahan Pakan Inkonvensional di Banyuwangi. Jurnal Medik Veteriner. 1 (1): $12-22$.

Amam dan P. A. Harsita. 2019. Efek domino performa kelembagaan, aspek risiko, dan pengembangan usaha terhadap SDM peternak sapi perah. Sains Peternakan. 17 (1): 5-11.

Amam, M. W. Jadmiko, P. A. Harsita, dan M. S. Poerwoko. 2019. Model pengembangan usaha ternak sapi perah berdasarkan faktor aksesibilitas sumber daya. Jurnal Sain Peternakan Indonesia. 14 (1): 61-69.

Amam dan Soetriono. 2019. Evaluasi Performa Kelembagaan Peternak Sapi Perah Berdasarkan Aspek Risiko Bisnis dan Pengembangan Usaha. Jurnal Ilmu dan Teknologi Peternakan Tropis. 5 (3): 8-13.

Anggraeni, A. dan E. Mariana, 2016. Evaluasi Aspek Teknis Pemeliharaan Sapi Perah Menuju Good Diary Farming Practices pada Peternakan
Sapi Perah Rakyat Pondok Ranggon. Jurnal Agripet. 16 (2): 90-96.

Handayanta, E. 2002. Optimalisasi Penggunaan Daun Ubi Kayu sebagai Pakan Ternak Ruminansia. Carakatani. 17 (2): 41-48.

Komar, A., S. B. K. Prajoga, dan Hermawan. 2010. Peran Usaha Perbibitan dalam Pengembangan Ternak Sapi Perah di Indonesia. Jurnal Ilmu Ternak. 10 (1): 7-13.

Jumriah, S., A. M. Tolleng, dan Umar. 2016. Pengaruh Pemberian Pakan Konsentrat dan Urea Molases Blok (UMB) terhadap Hematokrit Sapi Potong. Jurnal Ilmu dan Industri Peternakan. 2 (3): 1-6.

Makin, M. dan D. Suharwanto. 2012. Performa sifat-sifat produksi susu dan reproduksi sapi perah fries holland di Jawa Barat. Jurnal Ilmu Ternak. 12 (2): 39-44.

Mariyono dan N. H. Krishna. 2009. Pemanfaatan dan Keterbatasan Hasil Ikutan Pertanian serta Strategi Pemberian Pakan Berbasis Limbah Pertanian untuk Sapi Potong.

Nasrul, W. 2012. Pengembangan Kelembagaan Pertanian untuk Meningkatkan Kapasitas Petani terhadap Pembangunan Pertanian. Jurnal Menara Ilmu. 3 (29) 166-174.

Nurhayu, A., A. Ella, dan M. Sariubang. 2017. Perbaikan Pakan pada Sapi induk Sapi Perah sedang Laktasi di Kabupaten Enrekang, Sulawesi Selatan. Seminar Nasional Teknologi Peternakan dan Veteriner. Makassar. pp 132-138.

Riski, P., B. P. Purwanto, dan A. Atabany. 2016. Produksi dan Kualitas Susu Sapi 
FH Laktasi yang Diberi Pakan Daun Pelepah Sawit. Jurnal Ilmu Produksi dan Teknologi Hasil Peternakan. 4 (3): 345-349.

Sulistyati, M., Hermawan, dan A. Fitriani. 2013. Potensi Usaha Sapi Perah Rakyat dalam Menghadapi Pasar Global. Jurnal Ilmu Ternak. 13 (1): 17-23.

Sunu, K. P. W., Hartutik, dan Hermanto. 2013. Pengaruh Penggunaan Ajitein dalam Pakan terhadap Produksi dan Kualitas Susu Sapi Perah. Jurnal IlmuIlmu Peternakan. 23 (2): 42-51.
Susilawati, T. 2011. Tingkat Keberhasilan Inseminasi Buatan dengan Kualitas dan Deposisi Semen yang Berbeda pada Sapi Peranakan Ongole. Jurnal Ternak Tropika. 12 (2): 15-24.

Wiyono, G. 2011. Merancang Penelitian Bisnis dengan Alat Analisis SPSS 17.0 dan Smart PLS 2.0. Penerbit: Unit Penerbit dan Percetakan STIM YKPN. Yogyakarta. 